\title{
Government Wrong Policy Provides Tax Incentives to MSMEs During the Covid-19 Pandemic
}

\author{
Tri Murti Lubis ${ }^{1, *}$ Sunarmi Sunarmi ${ }^{2}$ \\ ${ }^{1}$ Doctoral Program in Law, Faculty of Law, Universitas Sumatera Utara \\ 2 Professor of Bankruptcy Law, Faculty of Law, Universitas Sumatera Utara \\ Email: agg.7785@gmail.com
}

\begin{abstract}
The Covid-19 Pandemic period has passed for the past 2 (two) years, causing changes in the order of life, both in the world and in Indonesia. All activities are carried out online, including in work and business. Various government policies have been carried out to support the country's economy by increasing the implementation of policies in the business sector. The economic stimulus provided to the community and MSMEs includes pre-employment cards, presidential assistance to MSMEs, and tax incentives. The policy aims to support MSME businesses, encourage public participation and knowledge of taxation. Qualitative data analysis techniques are carried out by collecting, sorting, analyzing sources of legal material, and finally concluding the data. Based on the results of the study, the MSME economic rescue policy made by the Government of the Republic of Indonesia was deemed less effective because health services to the community were not felt. According to the utility theory, citizens as a society need to be saved by implementing policies in the health sector first, then policies in the economic field are implemented.
\end{abstract}

Keywords: Sustainability of MSME, tax incentives, Covid-19, and New Normal Era.

\section{INTRODUCTION}

\subsection{Background}

The Covid-19 pandemic has restrained the State of Indonesia for 2 (two) years, resulting in changes in the order of people's lives. Various policies have been carried out by the Government of Indonesia to prevent massive transmission of Covid-19, one of which is by limiting activities outside the home.[1]

The state of the world in 2020, is experiencing a global pandemic of the spread of Corona Virus Disease19 or better known as Covid-19. Meanwhile, in 2021, other countries have recovered from the pandemic conditions, and there are even countries that hold football matches. Indonesia has also been affected by the spread of this virus. As a result, the Indonesian people are currently being hit by social phobia with the Covid-19 outbreak which gave rise to an emotional response in the form of fear and threats of being infected with Covid-19 and even resulting in death. In addition, the public is increasingly worried because the handling of Covid-19 prevention is considered not optimal and the number of infected people is increasing, either with symptoms or without symptoms.

Kennedy \& Suhendarto, the World Health Organization (WHO) announced Covid-19 as a global pandemic on March 11, 2020.[2] For almost two years from March 2020 to October 2021, Indonesia was in an unusual condition, namely with the implementation of Scaled Social Restrictions. Large (PSBB) and the Enforcement of Restrictions on Community Activities (PPKM), which prohibits community activities outside the home, especially MSMEs to live and make a living. In this condition, there are many impacts experienced by all elements of the nation, both the government and society, including MSMEs.[3]

All activities are carried out as much as possible online (online) to avoid large-scale gatherings of people. Therefore, there has been an automatic increase $20 \%$ in internet usage penetration during work (Work From Home), school (School From Home), or other activities carried out online.[4] No exception, this also has an impact on people's living habits today. This includes people who are working in the MSME sector.

The government has provided a policy by disbursing several funds from the State Budget and Regional Revenue and Expenditure Budgets to the Village Revenue and Expenditure Budgets which were deployed to overcome the problem of handling the Covid-19 virus, both in terms of health, social, education, to the economy. However, over time, policies to limit community mobility such as large-scale social restrictions (PSBB) in several areas have had a very visible impact on the economic sector. So that the community's economy is getting weaker due to these restrictions.[5] 
On the other hand, the number of people with the Covid19 virus continues to increase every day in Indonesia. Until mid-November 2020, the government broadcast more than 671,778 people who were confirmed positive for Covid-19 and the death toll of 20,085 people also continued to increase.[6] Meanwhile, in terms of economic strength, there has been a weakening of the ability to resolve this pandemic due to a lack of state revenue.

The government decided to save the country by enacting a new life order or called the "New Normal Era". New Normal is a new paradigm of life, where humans must make peace side by side with Covid-19, namely living according to health protocols, such as a healthy and clean lifestyle and using masks as long as a vaccine has not been found. The new normal for the economic sector aims to restore community activities, one of which is to improve income temporarily lost due to restrictions.[7]

Now, the government is trying to open several business sectors and continues to encourage MSMEs to carry out online activities, but still monitoring and gradually increasing tax revenues. To maintain business continuity while at the same time saving the national economy, the Government has implemented various socio-economic policy programs, including policy incentives and tax facilities that can be utilized by taxpayers.

For this reason, MSME actors are advised to take advantage of the tax policy in PMK No. 44/PMK.03/2020 concerning Tax Incentives for Taxpayers Affected by the Covid-19 Pandemic provides several tax incentives, including PPh Article 21 Borne by the Government (DTP) for workers with a gross income of not more than Rp. 200 million per year, Final PPh MSME DTP, the exemption of Article 22 Import PPh, a 30 percent reduction in Article $25 \mathrm{PPh}$ installments, and accelerated Value Added Tax (VAT) refunds. While PMK No. 28/PMK.03/2020 concerning the Provision of Facilities for Goods and Services Needed in the Context of Handling the Covid-19 Pandemic, provides about eight incentives for a period of six months starting from April 2020 to September 2020. Exactly on June 8, 2020, there have been 358,966 applications approved incentives. However, in Perpu 1 of 2020 which has been approved by the DPR into Law no. 2 of 2020. Three tax policies are important to be utilized by the public, namely the adjustment of the Income Tax rate for domestic corporate taxpayers and permanent establishments, the tax treatment in Trading activities through the Electronic System (PMSE), and the extension of time for the exercise of rights and fulfillment of tax obligations.[8]

The condition of the Covid-19 pandemic has harmed business and the economy, even business, and economic uncertainty have become a very frightening specter for MSME actors and almost all business sectors have received negative impacts from business uncertainty, including some businesses that have started to stop operating which eventually suppress economic growth.
The Large-Scale Social Restriction option certainly has consequences for the government, namely the responsibility of the government or the state to the community during the Covid-19 pandemic. The state's responsibility to the community in the Covid-19 pandemic has become very important, given that the people are the 'owners' of the highest sovereignty in Indonesia.[9] This means that all aspects of government power come from the people. This shows that the people have a principal and central position in the sustainability of the government of a country. The state is the 'tool' of society to achieve the nation's expectations.

Such construction of thinking should also apply to the policy of Large-Scale Social Restrictions. Moral and legal responsibilities to the community are still on the shoulders of the government. Although during the Covid19 pandemic, the state must be faithful to carry out national and state activities with consideration of conscience and moral values that grow and develop in society to realize the ideals of law, namely Pancasila. However, the act of establishing a health emergency status raises a problem, namely whether the Covid-19 emergency in Indonesia is the same as a 'state of danger' or a "forced crisis".[10] This is indicated by the determination of the 'state of danger' status for the Covid19 pandemic with the Presidential Decree on Health Emergencies by the government, but on the other hand, the government has determined that the Covid-19 pandemic is a "forced urgency" with the issuance of a Government Regulation instead of Law (Perpu) No. 1 the Year 2020.

The stipulation of emergency legal status in Indonesia must be based on Article 12 of the 1945 Constitution of the Republic of Indonesia (hereinafter referred to as the 1945 Constitution of the Republic of Indonesia) which states that the President declares a state of danger; The conditions and consequences of a dangerous situation are stipulated by law, and the formulation of Article 22 Paragraph (1) of the 1945 Constitution of the Republic of Indonesia which states that in the case of a compelling emergency, the President has the right to stipulate government regulations instead of law.

In the case of a 'dangerous situation', the determination of the emergency status is also based on Government Regulation instead of Law no. 23 of 1959 concerning the Revocation of Law no. 74 of 1957 and the Determination of the State of Danger. However, the determination of a "state of danger" using this rule is considered irrelevant to the current situation.

\subsection{Research Question}

In this paper, we will examine and analyze the wrong policies of the Government of the Republic of Indonesia in providing incentives to MSMEs during the Covid-19 Pandemic. The problems can be formulated as follows: What is the policy of the Government of the Republic of Indonesia in providing incentives to MSMEs during the Covid-19 Pandemic Period. 


\section{METHOD}

This paper uses a normative legal research method that highlights the policies of the Government of the Republic of Indonesia. The basis used as a knife of analysis is the theory of legal expediency. The data used are secondary data sourced from interviews in the field to small and micro business actors, especially in the Medan City area. In addition, international and national journals are also used as sources of legal material.

\section{RESEARCH RESULTS AND DISCUSSION}

\subsection{Utility Theory}

The legal theory used in this research is the theory of utilitarianism from Jeremy Bentham (1748-1873) which is called Utility Theory (the greatest happiness for the greatest number of people).[11] Utility theory by Jeremy Bentham which says that the usefulness of the law is for the benefit of the community at large. When you meet a case where the problem is like a double-edged sword. The measure is the greatest happiness for as many people as possible.[12]

\subsection{MSME Opportunities By Utilizing Tax Incentive Policies During the Covid-19 Pandemic and New Normal Era To Survive}

Research findings from primary data from in-depth interviews with respondents include the business profile of each MSME, tax payments for MSME actors before the incentive policy, MSME tax compliance potential after the enactment of the Minister of Finance Regulation no. 44/PMK.03/2020.[13]

By the tax policy set by the Government in Government Regulation of the Republic of Indonesia, Number 23 of 2018 concerning Income Tax (PPh) on income from business received or obtained by Taxpayers who have a certain gross turnover, effective from July 1 , 2018, this regulation is known as Government Regulation RI No. 23 of 2018. This Government Regulation is still the reference for the MSME tax rate, which is 0.5 percent of gross turnover per month. The purpose of this rate reduction is to explore the potential of MSME taxpayers because of the increasing number of MSME actors in Indonesia and support from the government so that MSMEs are growing.

During the current Covid-19 pandemic, public health remains a top priority. Therefore, the government does not remain silent in this situation. To maintain stability and restore the national economy, the government issued several policies to continue to support MSMEs during the pandemic. The policy is regulated in Government Regulation (PP) No. 23 of 2020 concerning the Implementation of the National Economic Recovery Program (PEN) which is a mandate from Perppu No.
1/2020 includes tax incentives, interest subsidies, and guarantees for new working capital for MSMEs.

Through the Regulation of the Minister of Finance No. 44/PMK.03/2020 the government replaces the Minister of Finance Regulation No. 23/PMK.03/2020 by introducing a new type of tax incentive, namely Final Income Tax based on PP 23 Borne by the Government (DTP). The background of the tax incentives for the Final PPh DTP is an effort to expand the scope of tax incentives due to the impact of Covid-19 which also reaches MSME actors. With the tax incentives, MSME actors are exempt from paying Final Income Tax Tax Government Regulation no. 23 during the April 2020 to September 2020 tax period. To take advantage of these tax incentives, MSME taxpayers must apply for a Certificate first on the www.Pajak.go.id page. After that, MSME taxpayers submit a DTP Final Income Tax realization report which includes Income Tax payable on income received or earned and is attached with a Tax Deposit Slip or a printed billing code. The report must be submitted every month and no later than the 20th of the following month after the tax period ends via the www.Pajak.go.id page using the Covid-19 Incentive eReporting service menu. The report must be submitted on time for the incentives to be utilized.

\subsection{Pre-Employment Card Policy Risks Not Targeting}

One of the differences in the 2020 State Revenue and Expenditure Budget (APBN) compared to the previous period is the emergence of the allocation of funds for the Pre-Employment Card program. The APBN allocates a budget of Rp. 10 trillion to be given to 2 million beneficiaries. This program is considered as one way to improve the quality of human resources (HR). Unfortunately, the pre-employment card program is considered to be still unclear, so there is a risk that it will not be right on target. Until now, the government has not determined the criteria for the people who are entitled to receive these benefits.[14]

The availability of data is a problem in using the budget because the government does not yet have a national worker database. "Who is entitled to receive this Pre-Employment Card? The problem is first, there is no strong database. If the poor people can be in TNP2K (National Team for the Acceleration of Poverty Reduction). Thus, if the funds are given to the community unfairly, jealousy and moral hazard will arise.

The National Labor Force Survey (Sakernas) data produced by the Sub-Directorate of Labor Statistics of the Central Statistics Agency (BPS) is also considered not to cover the entire workforce in Indonesia. This Sakernas employment statistics data is only a sample. The implementation of this Pre-Employment Card is very limited.

Previously, the Government emphasized that state spending in the form of pre-employment programs would 
be used to improve the quality of Human Resources and continue social protection programs to address demographic challenges. "To increase access to skills for young people, job seekers, and those who want to change jobs, the Government in 2020 will initiate the PreEmployment Card program", the Government conveyed the Introduction to the 2020 State Budget Plan for Fiscal Year along with its Financial Note.

In Book II of the Financial Note and the State Budget Plan for Fiscal Year 2020, it is stated that the presence of the Pre-Employment Card is not only motivated by complaints from job seekers who have difficulty getting jobs, but also because the competencies obtained from educational institutions are often not by the needs of the world of work.

The Pre-Employment Card is considered to be able to eliminate the gap between the competence of Human Resources and the needs of the world of work. In addition, the policy of providing Pre-Employment Cards will also be directed to encourage the improvement of skills needed now and in the future, especially in facing the era of industrial revolution 4.0 and digital technology. Through the Pre-Employment Card program, it is hoped that the competence of both new job seekers, job seekers who change professions, or victims of layoffs can fill the needs of the world of work, so that the problem of unemployment in Indonesia can be overcome.

According to the Financial Note, the 2020 PreEmployment Cards will be given to two million beneficiaries. The mechanism for distributing PreEmployment Cards will be carried out in two forms: First: Regular access Pre-Employment Cards, with a target of 500 thousand people. "This access is a continuation and expansion of ongoing activities, namely the provision of training and job competency certification to job seekers through Government LPKs including BLK, Private LPKs, and Industrial Training Centers, where training is conducted face-to-face. The target of this scheme is new job seekers (skilling) and job seekers who change professions or are victims of termination of employment (re-skilling).

Second, Digital Access Pre-Employment Card with a target of 1.5 million people, mainly for the young age group (skilling and re-skilling). It is emphasized in this book, to support the implementation of the 12-year compulsory education program, the population aged 1518 years is not included in the target. Through this mechanism, beneficiaries can choose the type, place, and time of training through digital platforms such as GoJek, Tokopedia, and others. "Training can be carried out online or face-to-face. The training provider is a training institution according to the criteria determined by the government," the Government Finance Memorandum said. To run the program, the government allocates a budget of Rp. 8 trillion-Rp. 10 trillion.

Meanwhile, to provide maximum socio-economic effects, according to this Government Financial Note, the implementation of the Pre-Employment Card Program is designed by considering various aspects while still taking into account the principles of budget effectiveness and efficiency. According to the government, this program will involve various parties such as Ministries/Institutions (K/L), public and private training institutions, job search companies, digital platforms, and also the beneficiaries themselves.

In addition, to deal with changes in the economic structure towards the Industrial revolution 4.0, the implementation of the Pre-Employment Card program needs to be developed and designed digitally to complement the format that has been implemented so far. Therefore, to run this program, a management agency or Project Management Office (PMO) is needed that will handle the implementation of the Pre-Employment Card program, both regular and digital access.

\subsection{Inappropriate Policy Providing Presidential Assistance to MSMEs during the Covid-19 Pandemic}

In the Covid-19 pandemic situation, the position of MSMEs may be to dominate the domestic market during a pandemic, especially when import needs cannot run as in normal situations. SMEs can be a solution to meet the needs. However, this potential cannot be realized because the tap for imports of raw materials is still open so that domestic production is not absorbed optimally. This makes it difficult for MSME players to penetrate the domestic market for raw material matters.[15]

In addition, the decline in trade volume was also experienced by MSME players who export abroad. On the other hand, those who work in tourist destinations are also experiencing the impact of the pandemic due to travel restrictions that have paralyzed the tourism sector. With a large number of MSME players, the impact of the pandemic will be felt by them and can then hamper the growth of the national economy. Therefore, the government first includes MSME actors in the poor and vulnerable categories of the poor affected by Covid-19 as recipients of government assistance. In addition, the government has also implemented various special policies for MSMEs to be able to overcome economic pressures as a result of the Covid-19 pandemic.

The priority of support for MSMEs is also evident from the government's efforts in overcoming the problem of the many slices of ministries that handle MSMEs. In addition to the Ministry of Cooperatives and SMEs, various ministries have special programs for MSMEs, namely the Ministry of Social Affairs, the Ministry of Agriculture, the Ministry of Maritime Affairs and Fisheries, the Ministry of Public Works, as well as Public Housing and the Ministry of Industry. To overcome this, in July 2020 discussions were held between ministries and institutions related to MSMEs initiated by the Ministry of Cooperatives and SMEs. In the discussion, it was agreed that to save the country's economy, MSMEs should be the first to be saved. 
The government's support for MSMEs during the Covid-19 pandemic is manifested in six policies that can be classified into three policy groups, namely restructuring MSME loans, working capital loans, and other support. This support is carried out by the government in collaboration with Bank Indonesia (BI) and the Financial Services Authority (OJK).

The MSME loan restructuring policy was carried out by: 1) relaxing the assessment of asset quality and 2) deferring principal and interest subsidies. The working capital policy is carried out by providing: 3) working capital loans with low-interest rates and 4) guarantees to Askrindo and Jamkrindo. Meanwhile, another support for MSMEs is carried out by 5) providing incentives for MSME final income tax borne by the government and 6) presidential assistance for productive micro-enterprises.

The first MSME loan restructuring was carried out by relaxing the asset quality assessment based on the Financial Services Authority Regulation no. 11/POJK.03/2020 and 14/POJK.05/2020. Determination of asset quality on loans of up to Rp 10 billion can only be based on the accuracy of principal/interest payments. In addition, a restructuring was carried out, namely debtor credit affected by Covid-19 was determined to be smooth since it was restructured and the restructuring was carried out without a ceiling limit/type of financing.

The restructuring of MSME loans was also carried out with a postponement of principal and subsidies. This policy has a legal umbrella from the Minister of Finance Regulation No. 65/PMK.05/2020 which was later updated with PMK No. 85/PMK.05/2020. Interest subsidies or margin subsidies are given to MSME debtors with a credit or financing ceiling of a maximum of IDR 10 billion for a maximum period of 6 months. This policy comes into effect from May 1, 2020, to December 31, 2020. There are four criteria for candidates to receive this interest subsidy or margin subsidy. First, it has a credit or financing debit balance until February 29, 2020. Second, it is not included in the national black list. Third, having a current performing loan category (collectibility 1 or 2 ) calculated as of February 29, 2020. Fourth, having a TIN or registering to get a TIN. Those who take Super Micro People's Business Credit (KUR), namely loans of up to Rp. 10 million, get a maximum interest subsidy of 25 percent for six months.

Furthermore, for micro, small, and medium (MSMEs) KUR debtors with loans of Rp. 10 million to Rp. 500 million, they get an interest subsidy or margin of 6 percent for the first three months and 3 percent for the following three months. Meanwhile, KUR MSMEs debtors with loans of IDR 500 million to IDR 10 billion will receive an interest subsidy or margin of 3 percent for the first three months and 2 percent for the following three months. In addition, debtors from this group must obtain restructuring from credit or financing providers. Meanwhile, for debtors who have several credit contracts or cumulative financing of IDR 500 million to IDR 10 billion, interest subsidies or margin subsidies are given for at most one credit or financing agreement.

The first working capital policy is carried out by providing low-interest working capital credit through the placement of state money in the form of deposits and/or government demand deposits at partner commercial banks. The government places funds of IDR 30 trillion in partner commercial banks for 6 months. The placement of government funds is carried out to accelerate lending, especially MSMEs and labor-intensive industries in the context of accelerating the economic recovery of the lower class. This policy is regulated in the Minister of Finance Regulation No. 70/PMK.05/2020 which was updated with PMK No. 104/PMK.05/2020.

The government stipulates four criteria for partner commercial banks to be given placements of funds. First, the commercial bank business license is still valid. Second, business activities are located in Indonesia and the majority of owners are Indonesian citizens/legal entities/government. Third, the minimum level of health is composite 3 which has been verified by OJK. Fourth, carry out banking activities that support the acceleration of PEN, namely credit expansion to cooperative-UMKM debtors and providing financing support to financial institutions that carry out credit expansion to cooperative-UMKM debtors.

In addition, commercial banks partnering with state money placement are prohibited from doing four things. First, using placement funds to buy state securities (SBN). Second, using placement funds for foreign exchange transactions. Third, charge service fees including administrative costs. Fourth, withholding/collecting remuneration obtained from the placement of state money. The government also provides guarantees for working capital loans for MSME actors. The MSME working capital credit guarantee scheme has been regulated through Minister of Finance Regulation No. 71/PMK.08/2020.

MSME support is also carried out by providing the President's Assistance for Micro Business Productivity (BPUM). The government provides direct assistance of Rp. 2.4 million per recipient or Rp. 600 thousand per month for four months. This assistance is given to 12 million micro-enterprises who are not currently receiving bank credit. The criteria for recipients of Presidential Assistance for productive micro-enterprises are Indonesian citizens who have an ID card, have a microbusiness as evidenced by a statement letter from the proposing institution, and have a bank account at a commercial bank.

In the first stage, the Presidential Assistance for productive micro-enterprises was given to 9,162,486 micro-enterprises as of July 28, 2020. The Presidential Assistance was distributed through six institutions, namely PT Pegadaian with 59.37 percent of recipients, Himbara with 32.09 percent of recipients, Dinas Cooperatives and SMEs throughout Indonesia accounted for 5.87 percent of the total recipients, the Cooperative 
Movement of 1.77 percent of the recipients, Asbanda of 0.88 percent of the total recipients, and Perbarindo of 0.03 percent of the recipients. In addition to financial support, affected MSME workers are also encouraged to take advantage of the pre-employment card program. It includes training costs of Rp. 1 million, training incentives of Rp. 600 thousand per month for four months, and work survey incentives of Rp. 50 thousand per survey for three surveys.

The initial scheme of the pre-employment card program targeted 2 million people, namely job seekers, workers or workers who were laid off, as well as workers who needed competency improvement. In response to the impact of Covid-19, the target for pre-employment card beneficiaries has been increased to approximately 5.6 million people, with the priority being laid-off workers and affected MSME actors with a total budget of IDR 20 trillion.

\subsection{Inappropriate Policies Provide Tax Incentives During a Pandemic}

Indonesia's policies in dealing with the Covid-19 pandemic are unclear. The spread is increasing because Indonesia uses a "herd immunity" strategy, where healthy people protect sick people. So that healthy people grow strong immune systems.[16]

The problem is that the herd immunity policy is implemented with the wrong target because the government provides stimulus in the form of "PreEmployment Cards" and "Presidential Assistance", and "Tax Incentives" which incidentally are assistance to the community in dealing with the Covid-19 Pandemic. While in the United States, and other European countries, implementing "herd immunity" by giving vitamin injections to every citizen, will increase body resistance and immunity against Covid-19. The goal is that citizens can work optimally and turn the wheels of the country's economy.

Based on the results of interviews and observations in the field with several micro-enterprises in the province of North Sumatra, especially in the city of Medan. Information was obtained that, among the six respondents interviewed, only one respondent received credit facilities from a Financial Institution (Bank) and received assistance from the Industry and Trade Office of North Sumatra Province, namely the shoe craftsman. Muhammad Iqbal. Based on the observations and deepening (observations) made, business actors an. Muhammad Iqbal received credit facilities and assistance from the North Sumatra Provincial Government because the business in question can be categorized as a medium business, not a micro business. In terms of loan facilities obtained from Bank Mandiri of Rp. 50,000,000,- by using the guarantee of Proof of Ownership of Motorized Vehicles (BPKB) for the car. Meanwhile, the other five respondents have never received loan facilities from financial institutions, and have never received assistance from the local government.
One of the important pieces of information obtained from the five respondents who did not get credit facilities from Financial Institutions (Banks) was regarding collateral, which is currently one of the requirements for applying for credit loans. Currently, collateral is one of the mandatory requirements in applying for credit loans for micro and small businesses in North Sumatra Province.

The majority of micro and small business actors interviewed complained about the difficulty of obtaining credit facilities from financial institutions or assistance from the Local Government due to complicated requirements (using collateral) and coupled with relatively high-interest rates so that micro-business actors Minor refused to apply for a credit facility to a Financial Institution.

In addition, the fact that the distribution of credit made by Financial Institutions that have Micro Business Units to micro and small business actors in North Sumatra Province is still not maximized. Financial Institutions limit the space in terms of lending to micro and small business actors. With a large credit limit limitation, it requires collateral, as well as the provision of relatively high-interest rates. So that the majority of micro and small business actors in North Sumatra were discouraged from applying for business capital loans to financial institutions. Thus, it can be concluded that the Financial Institutions in North Sumatra have not been able to support the development of micro and small enterprises to improve the welfare of the people in North Sumatra Province.

Indonesia, which provides economic stimulus with "Pre-Employment Cards", "Presidential Assistance", and "Tax Incentives" to Micro, Small, and Medium Enterprises (MSMEs) in terms of legal benefits is an inappropriate policy. Because ensuring the health of citizens is everything compared to doing economic stimulus.

\subsection{The State's Responsibility to Citizens During the Covid-19 Pandemic}

The COVID-19 pandemic period certainly gives the government the responsibility for order, security, comfort, and public welfare. The responsibility of the state can be seen in the fourth paragraph of the Preamble to the 1945 Constitution of the Republic of Indonesia, namely protecting the entire Indonesian nation and the entire homeland of Indonesia, promoting public welfare, educating the nation's life, and participating in carrying out world order based on independence, peace. immortality and social justice.

The four responsibilities above are the mandate of the nation's founders for the administration of the state. Then, we all know that Indonesia is a country that stands based on the law (rechtsstaat) not based on power alone. The 1945 Constitution of the Republic of Indonesia has a principal position as a guide for the governance and 
implementation of state, government, and social life, including affirming the existence of the concept of the state. This has been confirmed in Article 1 paragraph 3 of the 1945 Constitution of the Republic of Indonesia which reads that "the State of Indonesia is a state of law". The implication is that all state administration actions (including PSBB) must be based on legal instruments that lead to the state's goal, namely to protect and prosper.

The Large-Scale Social Restriction Policy must reflect social justice in all aspects and protect all elements of the nation. Although Large-Scale Social Restrictions create large excesses in all walks of life, the state is still obliged to fulfill all primary needs to reflect excellent public administration, service, empowerment, and development. On the other hand, of course, these policies can limit the movement of people. It must be understood that the presence of the Government Regulation on Large-Scale Social Restrictions cannot be separated from the presence of the Presidential Decree on Health Emergencies and the Health Quarantine Law. LargeScale Social Restrictions are one of the follow-up actions to a public health emergency.

Referring to Article 1 of the Government Regulation on Large-Scale Social Restrictions, Large-Scale Social Restrictions are restrictions on certain activities of residents in an area suspected of being infected with Corona Virus Disease 2019 (COVID-19) in such a way as to prevent the possible spread of Corona Virus Disease 2019 (COVID-I9). Considerations for implementing Large-Scale Social Restrictions include six elements, namely epidemiological, threat magnitude, effectiveness, resource support, operational technical, and economic, social, cultural, and security considerations.

This means that the implementation of Large-Scale Social Restrictions in an area requires holistic consideration by looking at the consequences and risks of implementing the policy. At a minimum, the reflection of the Large-Scale Social Restriction policy consists of holidays from schools and workplaces, religious activities, and activities in public places or facilities. However, in fact, the Large-Scale Social Restriction policy can be said to have 'came too late. Several educational institutions have made lecture holidays so that teaching and learning activities are online.

The impact of the Large-Scale Social Restriction policy must of course be overcome by the state, and of course, it is the responsibility of the state as well. Judging from Article 4 of the Government Regulation on LargeScale Social Restrictions, the Large-Scale Social Restrictions applied by the central government and local governments issue a responsibility or consequence, namely that both the central government and regional governments must pay attention to meeting the basic needs of the population, ranging from food, health services. , and other daily life.

The fulfillment of these primary needs is adjusted to the conditions of an area affected by Covid-19. If you look at the formulation of Article 4 of the Government
Regulation on Large-Scale Social Restrictions, the Government Regulation on Large-Scale Social Restrictions does not explicitly and clearly stipulate the state's responsibility for the policy of Large-Scale Social Restrictions towards the affected community, especially in the aspect of fulfilling the basic needs of the population.

Then, referring to Article 8 of the Health Quarantine Law, the central and local governments are still responsible for ensuring that all lines of community life needs are met during the implementation of Large-Scale Social Restrictions, especially medical needs, and food needs. The government's responsibility is also contained in the Health Quarantine Act. In terms of handling the Covid-19 pandemic, Article 4 of the Health Quarantine Law has given the responsibility to both the central government and local governments to protect public health from disease and/or health risk factors for everyone who is feared to cause public health problems. health emergency is carried out through health quarantine.

Furthermore, Article 6 of the Health Quarantine Law also provides responsibility for the central government and local governments for the readiness of all resources needed during the implementation of health quarantine. Therefore, everyone has the right to take responsibility from the government during the Covid-19 pandemic.

In essence, the responsibility of the state must remain loyal to the community, both in normal and abnormal conditions, as is the case in the Covid-19 pandemic. This responsibility is prioritized on community lines affected by the Covid-19 pandemic and government policies in handling Covid-19. When viewed from the perspective of consideration of Large-Scale Social Restrictions, the central and local governments should continue to carry out massive socialization to improve aspects of community discipline in complying with existing regulatory signs.

The central and local governments must as soon as possible identify areas and subjects that have the potential to contract Covid-19. Then, strict action is needed by the state apparatus against parties who violate the provisions of existing regulations. Furthermore, it is necessary to optimize the Covid-19 Task Force from the lowest level (RT/RW) to the highest level.

Paragraph IV of the 1945 Constitution of the Republic of Indonesia states that the state aims to protect the entire Indonesian nation and the entire homeland of Indonesia. 'Protecting' at this time can be concreted as the implementation of state responsibility to protect the public from the Covid-19 pandemic. This responsibility applies to all people both within the country and abroad. The responsibility of the state is also contained in Article $28 \mathrm{H}$ of the 1945 Constitution of the Republic of Indonesia, which states that the state is obliged to fulfill health services,[17] and is obliged to fulfill social security to the community.[18] 
The state must be responsible for providing adequate health service facilities in handling Covid-19.[19] Therefore, the implementation of the Large-Scale Social Restriction policy must pay attention to the fulfillment of social security and health services for the community. In addition, from a human rights perspective, everyone has the right to enjoy the highest attainable standard of physical and mental health during the Covid-19 pandemic.

The state must take primary responsibility for preventing, treating, and controlling the Covid-19 pandemic. The aspect of government responsibility can also be seen from the aspect of international law. The draft Articles of the Responsibility of State for Internationally Wrongful Acts from the International Law Commission states that there are two criteria for the meaning of the phrase "Internationally Wrongful Acts",[20] namely that the act must be related to the state based on international law and is a violation of international obligations carried out by a country. So, when viewed in international law, the wrong actions that have been carried out by the government must be accompanied by responsibility.

Such wrong actions can be in the form of intentional acts or negligence. The parameter of the "Internationally Wrongful Acts" is that no special mental condition is required in connection with the violation of the main obligations of the state, only the most important state actions are measured by the International Law Commission regardless of any intention.[21]

The state's responsibility can be said to be right if the injury is caused and is deemed to have originated from international wrongdoing by a state.[22] In determining the 'right' or 'wrong' of state action, it must be identified for a series of omissions or wrong actions committed by a country whether it has become a substantial factor causing losses during the Covid-19 pandemic or not. So, during the Covid-19 pandemic, action from the government can be said to be "Internationally Wrongful Acts" when the government's action actually causes the Covid-19 pandemic to worsen.

The international legal framework provides an obligation for states that violate international law to make full reparation for losses caused by wrongdoing internationally. The government must take legal action by the most specific international legal rules in regulating infectious diseases and public health, namely the International Health Regulations 2005.

A country's respect for the 2005 International Health Regulations is essentially aimed at preventing, protecting, controlling, and providing public health responses to the spread of the Covid-19 pandemic.[23] When viewed from Article 16 of the International Covenant on Economic, Social and Cultural Rights (ICESCR) 1966 as ratified by Indonesia with Law no. 11 of 2005 concerning the Ratification of the International Covenant on Economic, Social and Cultural Rights, the Indonesian government has the responsibility to do everything necessary to seek the prevention, treatment, and control of the Covid-19 pandemic.

In the case of Large-Scale Social Restrictions, the state must continue to guarantee the rights of the people related to economic and social aspects. So, even in the situation of dealing with Covid-19, the state can provide survival for the community. The state's responsibility to the community during the Covid-19 pandemic can also be seen from the aspect of Law no. 24 of 2007 concerning Disaster Management (hereinafter referred to as the Disaster Management Law). This is because Covid-19 has been declared a national non-natural disaster through Presidential Decree No. 12 of 2020 concerning the Determination of Non-Natural Disasters for the Spread of Corona Virus Disease 2019 (Covid-19) as National Disasters.

As a non-natural disaster, the state's responsibility for the Covid-19 pandemic is contained in Article 6 of the Disaster Management Law, namely being responsible for protecting the community from the impact of disasters, being responsible for guaranteeing the fulfillment of the rights of communities and refugees affected by disasters fairly and by service standards. minimum, responsible for the recovery of conditions from the impact of disasters. Local governments also have a responsibility in handling Covid-19.

Based on Article 8 of the Disaster Management Law, during the Covid-19 pandemic, the government must provide guarantees for the fulfillment of every person and refugee who has been affected by the Covid-19 pandemic by minimum service standards. Furthermore, the local government also protects the community from the impact of Covid-19. The government is also responsible for reducing the risk of Covid-19 and integrating Covid-19 risk reduction with development programs. Then, in the economic aspect, the government is also responsible for allocating the handling and handling of Covid-19 in the available Regional Revenue and Expenditure Budget.

The government should have imposed a regional quarantine as a follow-up to the public health emergency status. In fact, Article 56 of the Health Quarantine Law gives responsibility to the government for the necessities of life for people and food for livestock during the period of regional quarantine. Of course, this is different from Article 4 of the Government Regulation on Large-Scale Social Restrictions.

By not giving the government the obligation to give responsibility, the current government policy shows that the government is 'half-hearted' in ensuring the basic needs of the population. The government only prioritizes aspects of good faith, without the obligation to meet the primary needs of the community. The regional quarantine can be carried out by the government if the government is careful in managing aspects of financial planning. The central government and local governments can refocus and reallocate the budget. 
This is done to cut the discourse on spending by various institutions at the central and regional levels that are not a priority during the Covid-19 pandemic so that they can be allocated to handling Covid-19. The LargeScale Social Restriction Policy reflects that the current government's main priority is the public health aspect. However, other aspects of life also need to be considered, considering that aspects of human life are related to one another.

For this reason, the central government and regional governments are expected to 'embrace' relevant stakeholders who are also affected by the Covid-19 pandemic. This can be done by the government by buying farmers' crops, collaborating with Micro, Small, and Medium Units (MSMEs) to make personal protective equipment independently, and so on. This reflection can reflect that the state is really present in society.

However, seeing the problems that occurred, the government should have established a health emergency status with the option of locking options (regional quarantine). The reason is that the Large-Scale Social Restriction option seems to give the government a 'grey' position because the government is not obliged to bear all lines of people's lives, especially the primary needs of the community. On the other hand, the Large-Scale Social Restriction option also 'releases' the government's obligation to bear all the impacts that occur if a health emergency is imposed with the option of locking (regional quarantine) options.

\section{CONCLUSION}

From the results of the analysis and discussion that has been carried out, the conclusions of this study are: First, the business carried out by MSME actors is in the form of product innovation, so that the business opportunities that are carried out can increase sales at online stores during the Covid-19 pandemic and the new normal era. Second, MSME actors appreciate the tax incentive policies contained in the Regulation of the Minister of Finance No. 44/PMK.03/2020 and MSME actors stated that they had taken advantage of these tax incentives and continued to improve compliance with tax obligations. Third, MSME actors expect socialization and assistance to obtain more detailed information related to the latest tax regulations or policies. However, the incentives to the public during the Covid-19 pandemic were policies that were misdirected according to the theory of legal expediency.

Instead, the government should focus on managing the fate of its citizens by stimulating vaccination and giving vitamins to every citizen once a month. Increasing body resistance to survive amid the Covid-19 pandemic is a policy that is beneficial for the community as citizens who have rights that must be protected by the State. This is by the purpose of the state, which is to protect all of Indonesia's bloodshed, including citizens as a society.

\section{REFERENCES}

[1] Kumala, R., dan Junaidi A. (2020), "Strategi Bisnis dan Pemanfaatan Kebijakan Pajak di Masa Pandemi Covid-19 dan Era New Normal (Studi Kasus Pelaku UKM Marketplace)", Prosiding Seminar Stiami Vol. 7, No. 2, hlm. 98-103.

[2] Harian Kompas, "WHO Resmi Sebut Virus Corona Covid-19 Sebagai Pandemi Global”, diterbitkan Kamis, 12 Maret 2020.

[3] Kennedy, R. dan Suhendarto, B.P., (2020), "Diskursus Hukum: Alternatif Pola Pengisian Jabatan Kepala Daerah di Masa Pandemi Covid19”, Jurnal Pembangunan Hukum Indonesia Vol. 2 No. 2, hlm. 2.

[4] Badan Pusat Statistik (BPS), "Tak Semua Warga Bisa Bekerja dari Rumah Walau Ada Corona", https://databoks.katadata.co.id/datapublish/2020/0 6/02/tak-semua-warga-bisa-bekerja-dari-rumahwalau-ada-corona., diakses Senin, 22 Desember 2020.

[5] Harian Republika, "Pengalokasian Ulang APBN dan APBD Untuk Tangani Covid-19”, diterbitkan Rabu, 18 Maret 2020.

[6] Website Resmi Komite Penanganan Covid-19 dan Pemulihan Ekonomi Nasional, "Peta Sebaran", https://covid19.go.id/peta-sebaran., diakses Selasa, 22 Desember 2020.

[7] Wawan Mas'udi dan Poppy S. Winanti (Ed.), 2020, New Normal: Perubahan Sosial Ekonomi dan Politik Akibat Covid-19, Gadjah Mada University Press, Yogyakarta, hlm. 8.

[8] Suryo Utomo dalam Akhmad, N. "Pemanfaatan Insentif Pajak Terkait Covid-19 Masih Minim", https://www.topbusiness.id/37763/pemanfaataninsentif-pajak-terkait-covid-19-masih-minim.html., diakses Minggu, 20 Desember 2020.

[9] Pasal 1 ayat (2) Undang- Undang Dasar Negara Republik Indonesia Tahun 1945.

[10] Disantara, F.P. (2020a). Aspek Imunitas Dalam Penanganan Corona Virus Disease 2019. Istinbath: Jurnal Hukum, 17(1), p. 65-82.

[11] Siregar, M., 2009, “Modul Perkuliahan: Filsafat Hukum", Sekolah Pasca Sarjana Universitas Sumatera Utara, Medan.

[12] Jeremy Bentham dalam Magee, B., 2008, The Story of Philosophy: Kisah Tentang Filsafat, Edisi 
Indonesia, diterjemahkan Marcus Widodo dan Hardono Hadi, Kanisius, Yogyakarta, hlm. 182185 .

[13] Kumala, R., dan Junaidi A. (2020), "Strategi Bisnis dan Pemanfaatan Kebijakan Pajak di Masa Pandemi Covid-19 dan Era New Normal (Studi Kasus Pelaku UKM Marketplace)", Prosiding Seminar Stiami Vol. 7(2), hlm. 98-103.

[14] Ahmad, T. (2020) dalam Rizki, M.J. "Kebijakan Kartu Pra Kerja Berisiko Tak Tepat Sasaran", https://www.hukumonline.com/berita/baca/lt5d5a7 98cb68ce/kebijakan-kartu-pra-kerja-berisiko-taktepat-sasaran/., diakses Senin, 21 Desember 2020.

[15] Gitiyarko, V. (2020) "Kebijakan Perlindungan dan Pemulihan UMKM di Tengah Pandemi Covid-19”, https://kompaspedia.kompas.id/baca/paparantopik/kebijakan-perlindungan-dan-pemulihanumkm-di-tengah-pandemi-covid-19., diakses Senin, 21 Desember 2020.

[16] Signorelli, C., Zucchi, A., Tersalvi, C.A. et al. (2020). High seroprevalence of SARS_COV-2 in Bergamo: evidence for herd immunity or reason to be cautious?. Int J Public Health 65, 1815-1817. https://doi.org/10.1007/s00038-020-01524-X

[17] Pasal 28 H Ayat (1) UUD NRI 1945.

[18] Pasal 28 H Ayat (3) UUD NRI 1945.

[19] Pasal 34 Ayat (3) UUD NRI 1945.

[20] Distefano, G. (2019). State Responsibility for Internationally Wrongful Acts. In Fundamentals of Public International Law (pp. 637-805). Brill | Nijhoff.

[21] Suthar, A. B., Allen, L. G., Cifuentes, S., Dye, C., \& Nagata, J. M. (2018). Lessons Learnt from Implementation of The International Health Regulations: A Systematic Review. Bulletin of the World Health Organization, 96(2), 110-121E.

[22] Broberg, M. (2020). A Critical Appraisal of the World Health Organization's International Health Regulations (2005) in Times of Pandemic: It Is Time for Revision. European Journal of Risk Regulation, 11(2), p. 1-8.

[23] Gostin, L. O., \& Meier, B. M. (2019). Introducing Global Health Law. The Journal of Law, Medicine \& Ethics, 47(4), p. 788-793. 